DOI: $10.15421 / 272012$

УДК 929:75(092)+629.78

Е. П. Чистякова, О. О. Губка

Дніпропетровське міське Реріховське товариство, м. Дніпро, Україна

\title{
ЖИТТЯ І ТВОРЧІСТЬ С. М. РЕРІХА ТА ЙОГО ЗУСТРІЧІ 3 КОНСТРУКТОРАМИ КБ «ПІВДЕННЕ» В ІНДІЇ ЗА ПРОГРАМОЮ «ІНТЕРКОСМОС»
}

До 115-річчя від дня народження С. М. Реріха (1904-1993)

До 50-річчя запуску першого КА

за програмою «Інтеркосмос» (1969-1991)

E-mail: olyachaplits@gmail.com,dpro@rambler.ru

ORCID ID: https://orcid.org/0000-0001-6092-019X

\begin{abstract}
Анотація. Висвітлено основні віхи життєвого i творчого шляху видатного художника, мислителя і громадського діяча С. М. Реріха. Розказано також про радянсько-індійську співпрацю за програмою «Інтеркосмос» i про зустрічі конструкторів і вчених КБ «Південне» (м. Дніпропетровськ, нині - Дніпро) зі Святославом Реріхом у рамках цієї співпраці. Значущими для авторів стали відомості, отримані за допомогою методу інтерв'ю. За його допомогою вдалося зібрати цікаву і рідкісну інформацію у конструкторів космічних апаратів 3 КБ «Південне», a також отримати їх спогади про зустрічі зі Святославом Миколайовичем у маєтку Татагуні під містом Бангалором у 70-х роках XX століття. Саме в Бангалорі здійснювалося співробітництво радянської та індійської сторін, у результаті якого з'явилися перші індійські супутники «Аріабхата» та «Бхаскара», а успішний запуск цих супутників сприяв створенню і становленню національної космічної програми Індії.
\end{abstract}

Ключові слова: Святослав Реріх, програма «Інтеркосмос», радянсько-індійське співробітництво, КА «Аріабата», КА «Бхаскара».

\section{E. Chystiakova, O. Gubka}

Dnepropetrovsk city Roerich society, Dnipro, Ukraine

\section{LIFE AND CREATIVITY OF SVETOSLAV ROERICH AND HIS MEETINGS WITH DESIGNERS OF YUZHNOYE DESIGN OFFICE IN INDIA UNDER THE INTERCOSMOS PROGRAM}

\begin{abstract}
The article tells about the main milestones in the life and career of the outstanding artist, thinker and public figure Svetoslav Roerich. There are also talked about Soviet-Indian cooperation under the Intercosmos program and about the meetings of designers and scientists of the Yuzhnoye Design Office with Svetoslav Roerich in the framework of this cooperation. Information obtained using the interview method became significant for the authors. Using this method, it was possible to collect interesting and rare information from the designers of spacecraft from the Yuzhnoye Design Office, as well as to get their memories of the meetings with Svetoslav Nikolaevich in the Tataguni estate near the Bangalore city in the 70 s of the 20th century. It was the Bangalore where the Soviet and Indian cooperation took place, as a result of which the first Indian
\end{abstract}


satellites Ariabhata and Bhaskara appeared. The successful launch of these satellites contributed to the creation and establishment of the national space program of India.

Keywords: Svetoslav Roerich, Intercosmos Program, Soviet-Indian Cooperation, Ariabata Spacecraft, Bhaskara Spacecraft.

\section{Вступ}

У 2019 рочі виповнилося 115 років від дня народження видатного художника і мислителя С. М. Реріха. 3 його ім'ям пов'язано багато ключових явищ, що відбувалися в духовно-культурному просторі планети в XX столітті. Як і всі члени унікальної сім'ї, він вирізнявся рідкісним синтезом різноманітних талантів і сфер їх застосування [6]. С. М. Реріх написав тисячі картин, низку книг керував великими культурно-освітніми установами та створював їх сам, координував роботу безлічі громадських організацій на кількох континентах, закладав основи нової науки, освіти і просвіти, зміцнював співпрацю між Індією і СРСР. Саме завдяки Святославу Миколайовичу відбулася найважливіша подія - передача спадщини родини Реріхів у 1990 році з Індії в Радянський Союз. Серед широкого кола тих, з ким спілкувався С. М. Реріх, були й учасники програми «Інтеркосмос». На сьогодні це маловідомий факт, який заслуговує на його висвітлення.

Матеріал і методи досліджень. Використано біографічний метод і метод інтерв'ю. Інтерв'юерами були конструктори КБ «Південне», які брали участь у програмі «Інтеркосмос» [5]. Джерела дослідження склали, в тому числі, видання Міжнародного Центру Реріхів на основі архівів, переданих С. М. Реріхом у складі спадщини в Радянський Союз [2; $3 ; 6]$.

\section{Результати та обговорення}

Святослав Миколайович Реріх народився 23 жовтня 1904 року в Петербурзі, 3 цим містом були пов'язані перші дванадцять років його життя. Він рано почав малювати і займатися ліпленням, відвідував уроки Школи Товариства заохочення мистецтв, готував декорації до домашніх постановок і навіть допомагав батькові в роботах над театральними ескізами. У 1913 році він вступив до відомої гімназії Карла Мая в Петербурзі, в якій навчався до 1916 року. 31919 року Святослав Реріх навчався в Лондоні, в Королівській академії мистецтв, де вивчав архітектуру, а через рік продовжив архітектурну освіту в США, спочатку в школі Колумбійського, а потім Гарвардського університетів, одночасно відвідуючи скульптурне відділення університету Массачусетса.

В Америці Святослав Реріх брав активну участь у роботі всіх культурнопросвітницьких організацій, створених Миколою Костянтиновичем та Оленою Іванівною Реріхами. У 19 років очолив Міжнародний мистецький центр «Corona Mundi» («Вінець Миру»), а згодом став віце-президентом Музею Миколи Реріха в Нью-Йорку [1].

У 1923 році Святослав Миколайович Реріх вперше відвідав Індію. Тут він познайомився 3 найзнаменитішими архітектурними шедеврами індійської культури, зі стародавнім і сучасним мистецтвом цієї країни. У 1924 році С. М. Реріх повернувся до США і розпочав участь у роботі 3 керівництва культурнопросвітницькими установами, пов'язаними 3 ім'ям М. К. Реріха. Саме завдяки Святославу Миколайовичу батьки і старший брат, що знаходилися на маршруті складної Центрально-Азійської експедиції, підтримували контакти із «зовнішнім 
світом». Це відкривало можливості для їх плідної наукової та дослідницької діяльності. Одночасно С. М. Реріх продовжував удосконалюватися в живопису, багато працював. У 1925 році йому було присуджено вищу нагороду на виставці в Філадельфії, де експонувалося близько ста його творів. Наступні досягнення молодого художника стають впевненими кроками на шляху до майстерності і досконалості.

Свій шлях художника С.M. Реріх почав як портретист і досяг у цьому жанрі найвищої майстерності. Тільки портретів свого батька він написав близько 30, один 3 них був придбаний Люксембурзьким музеєм у Парижі. В ту пору С. М. Реріху було всього 35 років. Галерея створених Святославом Миколайовичем портретів величезна, серед них особливо виділяються безцінні образи його батьків.

Продовжуючи в живопису традиції свого великого батька, М. К. Реріха, Святослав Миколайович пішов своїм власним шляхом. У його роботах немає ні тіні наслідування. У кожного з художників, батька і сина, свій стиль і своя унікальна техніка виконання. Крім портретного, С. М. Реріх звертається до пейзажного, епічного, жанрового та символічного живопису i в усьому проявляє себе як віртуозний майстер i натхненний експериментатор. «У картинах Святослава помічаємо саме гармонійну напруженість всіх частин картини. Велика якість творів, якщо в неї не вкралася байдужість. <..> Прекрасно, якщо дано в житті цей високий дар, яким все темне, все тяжке перетворюється в радість духу. I як радісно ми повинні вітати тих, хто волею долі можуть вносити в життя прекрасне», - писав M. K. Pepix [2].

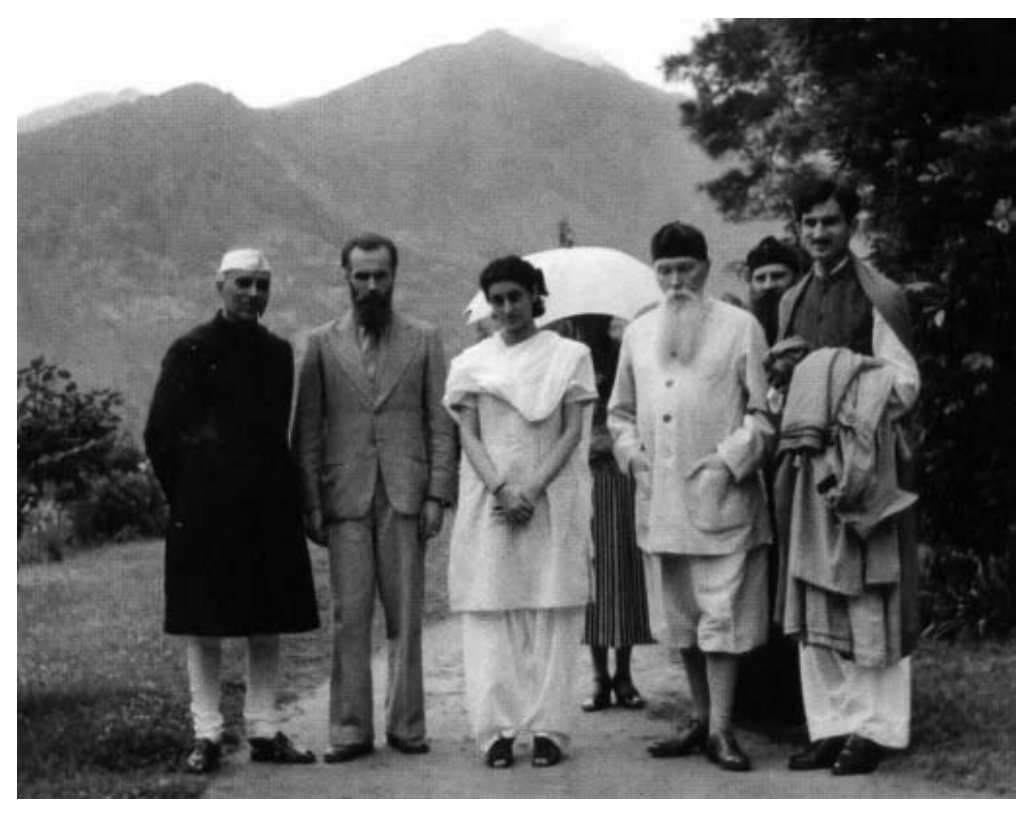

Джавахарлал Неру, С. М. Реріх, Індіра Ганді, О. І. Реріх (під зонтом), М. К. Реріх у Кулу (зліва направо). 1942

31931 року, постійно проживаючи в Індії, Святослав Миколайович бере активну участь в іiі суспільному та культурному житті. Він дуже любив цю країну, яка стала для нього другою батьківщиною. Унікальну красу, різноманітність культурних традицій i витонченість духовних досягнень Індії Святослав Миколайович Реріх оспівав у багатьох своїх чудових полотнах. Після 1947 р. С. М. 
Реріх проводить велику роботу, пов'язану з підписанням Пакту Реріха про захист культурних цінностей індійським урядом. Завдяки його зусиллям у серпні 1948 року Індія приєдналася до цього документа. Протягом наступних років художник брав активну участь у роботі зі збереження і захисту від руйнування пам'ятників давньоіндійської культури.

Святослав Миколайович брав діяльну участь у роботі Інституту Гімалайських досліджень «Урусваті». Очолюючи роботу природничо-наукового відділу, він проводив унікальні дослідження в різних областях природничонаукового знання. Цьому сприяв рідкісний дар духовного синтезу, яким він володів. В основі природничо-наукових інтересів С. М. Реріха лежало глибоко філософське розуміння природи як єдиного цілого, нерозривно пов'язаного 3 найважливішими космічними закономірностями. Коло його наукових інтересів вражає: орнітологія, ботаніка, мінералогія, тибетська фармакопея, хімія, астрологія, порівняльні релігієзнавство та філософія, мистецтвознавство, культурологія. Така різноманітна діяльність Реріха-вченого говорить про його безсумнівну приналежність до плеяди крупних натуралістів.

С. М. Реріх був не тільки художником світового рівня, а й великим мислителем і філософом, який постійно спостерігав і вивчав життя та його закони. Краса, іiі суть, її роль в еволюційному розвитку людства і пов'язані з цим енергетичні процеси складали основу філософських поглядів С. М. Реріха. «Великі твори $є$ скарбницями величезних енергій, які можуть активізувати і змінити мільйони глядачів, вплинути на численні покоління через передавання краси, яка випромінюється 3 них. <..> Чари почуттів, думок і сильних бажань великих майстрів що містяться у творі, випромінюються на глядача і пробуджують у нас схожі відповідні почуття, крім чисто енергетичного і духовного розуміння того, про що йдеться. Ми реагуємо на більш досконалі поєднання і називаємо їх прекрасними. <..> Така незвичайна влада мистецтва, прихована сила, завжди присутня і активна у великому творі», - писав художник. I ще: «Найбільшим вірним, найпростішим шляхом $\epsilon$ шлях краси. Бо йдучи ним у пошуках краси, ми незмінно йдемо шляхом, прокладеним еволюцією. Рух еволюційних сил протікає у глибині людського серця, і якщо тільки уважно прислухатися до його голосу, до цих космічних шепотів, ми будемо знати, куди йти, ми зможемо розпізнати ту мету, до якої рухається Природа» [3, c. 114].

Святослав Миколайович добре відомий як засновник і почесний президент культурно-просвітницького Центру мистецтв «Чітракала Парішад», створеного в Бангалорі в 1972 році, який став відділенням місцевого університету. Нині там експонуються картини М. К. Реріха і С. М. Реріха.

За видатні досягнення в галузі культури, а також за внесок у справу миру C. М. Реріх був удостоєний урядових нагород різних країн, серед яких вищий цивільний орден Індії «Падма-Бхушан», радянський орден «Дружба народів» i багато інших.

У 1989 році в Москві за ініціативою Святослава Миколайовича Реріха було створено радянський Фонд Реріхів. У березні 1990 року, виконуючи волю своїх батьків, він передав у цей фонд безцінну спадщину свій сім'ї - картини, предмети образотворчого та прикладного мистецтва, архів, бібліотеку, особисті речі. У 1991 році, з ініціативи С. М. Реріха, на базі спадщини, раніше переданої радянському Фонду Реріхів, було створено Міжнародний Центр Реріхів. Спадщина склала основу постійної експозиції громадського Музею імені М. К. Реріха МЦР, директором якого С. М. Реріх призначив відомого вченого-індолога Людмилу 
Василівну Шапошникову. Святослав Миколайович пішов 3 життя 30 січня 1993 року.

Низка епізодів життя С. М. Реріха була пов'язана з міжнародною космічною програмою «Інтеркосмос», в успішне здійснення якої вагомий внесок було зроблено і КБ «Південне». У 2019 р. виповнилося 50 років з дня запуску першого космічного апарата за програмою «Інтеркосмос».

Радянсько-індійське співробітництво було одним 3 найважливіших напрямків міжнародної співпраці для КБ «Південне» ім. М. К. Янгеля. Як відомо, важливим етапом програми космічних досліджень Індії стало створення власного індійського космічного апарата, підготовка фахівців у галузі космічних технологій, організація космічного виробництва. Для вирішення цих завдань уряд Індії звернувся за допомогою до Радянського Союзу. Практична реалізація угоди була покладена на КБ «Південне» - розробника ракет-носіїв і малих космічних апаратів серії «Космос» і «Інтеркосмос» [5].

Спільна розробка й успішний запуск перших індійських супутників «Аріабата», «Бхаскара-1», «Бхаскара-2» сприяли створенню і становленню національної космічної програми Індії. Громадськість і уряд цієї країни високо оцінили допомогу радянської сторони i, зокрема, колективу КБ «Пвденне». Найактивнішу участь у цих роботах брали співробітники КБ «Південне» В. М. Ковтуненко, А. М. Попель, С. І. Уваров, В. І. Драновський, В. С. Гладилін, А. П. Шураєв, В. С. Варивдін, Я. М. Вовк, І. М. Лисенко, Н. А. Шматок, Ю. В. Петров та інші.

Цікавою сторінкою історії космічної галузі нашого міста $\epsilon$ те, що вчені і конструктори КБ «Південне» в 1975-1981 роках, працюючи в Індії в місті Бангалорі в рамках програми «Інтеркосмос» за проектом «Аріабата - Бхаскара», неодноразово бували у великого художника і мислителя С. М. Реріха. В'ячеславу Михайловичу Ковтуненко - головному конструктору КБ-3 з виробництва літальних апаратів, його заступнику Анатолію Михайловичу Попелю, а також В. I. Драновському, В. С. Гладиліну, Ю. В. Петрову та іншим вченим-інженерам КБ «Південне» пощастило побувати в маєтку Святослава Реріха під Бангалором та побачити його картини.

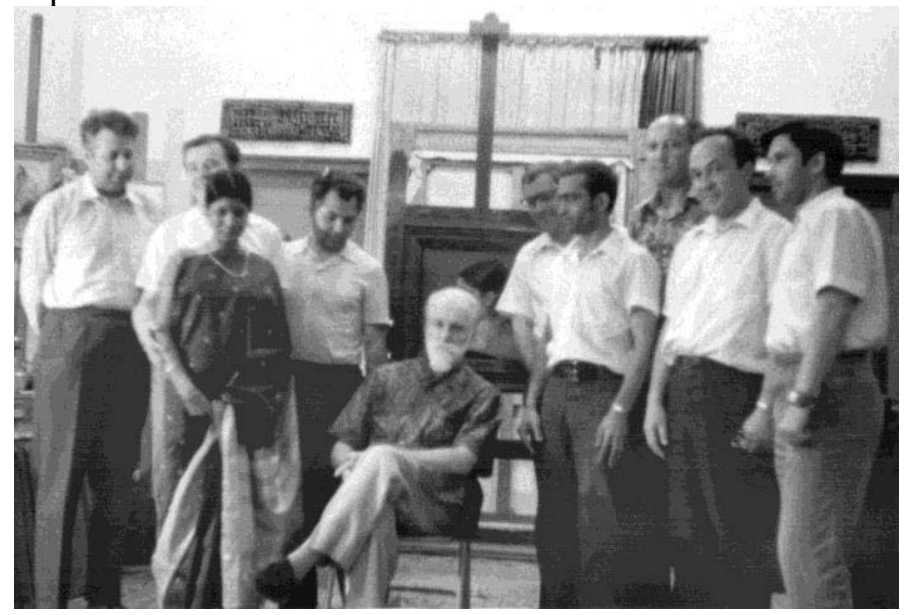

Учасники програми «Інтеркосмос» у майстерні Святослава Реріха. У центрі С. М. Реріх, 2-й зліва - О. Ф. Богомолов (ДКБ МЕI, Москва), 4-й зліва -

А. П. Шураєв, 2-й справа - А. М. Попель, 3-й справа - Я. М. Вовк (усі - КБ «Південне», Дніпропетровськ). Маєток Татагуні під Бангалором, Індія. 1976 р. 
А. М. Попель згадував, що, зупинившись в Бангалорі в готелі, директором якого був друг С. М. Реріха пан Микита, вчені делегації захотіли побачитися 3 відомим художником, який проживав у маєтку під Бангалором, і їм це вдалося. Делегації, які приїжджали в Індію за програмою «Інтеркосмос», неодноразово бували у Реріха, і якщо спочатку ці зустрічі були більш формальними, то потім зав'язалася справжня дружба [4].

Святослава Миколайовича цікавило все, що відбувалося в СРСР, як у культурному, так і в суспільному житті. Він виписував звідти книги, газети, журнали, і в його розмовах відчувалася любов до своєї Батьківщини. Вчені зазначали високу гостинність С. М. Реріха і його прекрасної дружини Девіки Рані, в минулому відомої індійської кіноактриси. Їх дуже вразило і те, що, незважаючи на довге проживання в іншій країні, мелодійна мова і акцент С. М. Реріха говорили про його петербурзьке походження.

Як згадують конструктори, зустрічі мали надзвичайно теплий і дружній характер, так як коло інтересів в областях науки, культури і суспільного життя було великим. Конструкторів ракетно-космічної техніки з Реріхом об'єднував Космос, адже Святослав Миколайович був не тільки художником і вченим, але й видатним мислителем космічного масштабу. Розмови з конструкторами і вченими торкалися багатьох питань 3 різних областей життя, адже Святослав Миколайович, як зазначає А. М. Попель, цікавився усім - наукою, мистецтвом, культурою. Відчувалась його висока освіченість, різнобічність інтересів, гострий розум i, безумовно, талант живописця. Показуючи вченим свої картини, Реріх розповідав про те, якими великими знаннями 3 області живопису, композиції, біології, хімії потрібно володіти, щоб створити справжній витвір мистецтва. Адже тільки постійно вдосконалюючись та здобуваючи нові знання, можна стати справжнім художником. Як зазначають ті вчені та конструктори, що спілкувалися 3 ним, Святослава Миколайовича в Індії любили і добре знали як відомого живописця, він був вхожий в усі кола суспільства. Саме С. М. Реріху доручили написати портрети Джавахарлала Неру, Індіри Ганді та інших відомих політичних діячів Індії, ці портрети і зараз знаходяться в індійському парламенті.

Святослав Миколайович також показував делегації вчених свою велику плантацію ефіроолійних дерев під Бангалором, єдину в Індії й одну 3 небагатьох у світі. Хотілося повертатися в його садибу ще і ще, тим більше що гостинний господар був завжди радий побачити вчених, дізнатися про життя в СРСР і показати їм свою творчість.

Цікаво, що в різний час у маєтку у С. М. Реріха бували багато відомих людей - Валентина Терешкова, Людмила Живкова, Олександр Кадакін, Юлій Воронцов і багато інших.

Крім відвідування маєтку С. М. Реріха, індуси підготували радянським фахівцям, що брали участь у програмі «Інтеркосмос», цікаву культурну програму, i така уважність, безумовно, позитивно позначилася на співпраці обох сторін.

\section{Висновки}

Співпраця за програмою «Інтеркосмос» в області створення перших індійських космічних апаратів, що виникла в 70-80-х роках XX століття між Індією і СРСР, виявилася успішною і плідною. В результаті досліджень за допомогою КА «Аріабата» і «Бхаскара» були отримані дані, необхідні для розвитку багатьох галузей науки, здійснено внесок в удосконалення технологій освоєння космосу. 
Експозиція, присвячена першим супутникам Індії, «Аріабаті» і «Бхаскарі», зараз перебуває в місті Бангалор у величезному інтерактивному Промисловотехнологічному музеї ім. Вісвесварая, в залі Космосу.

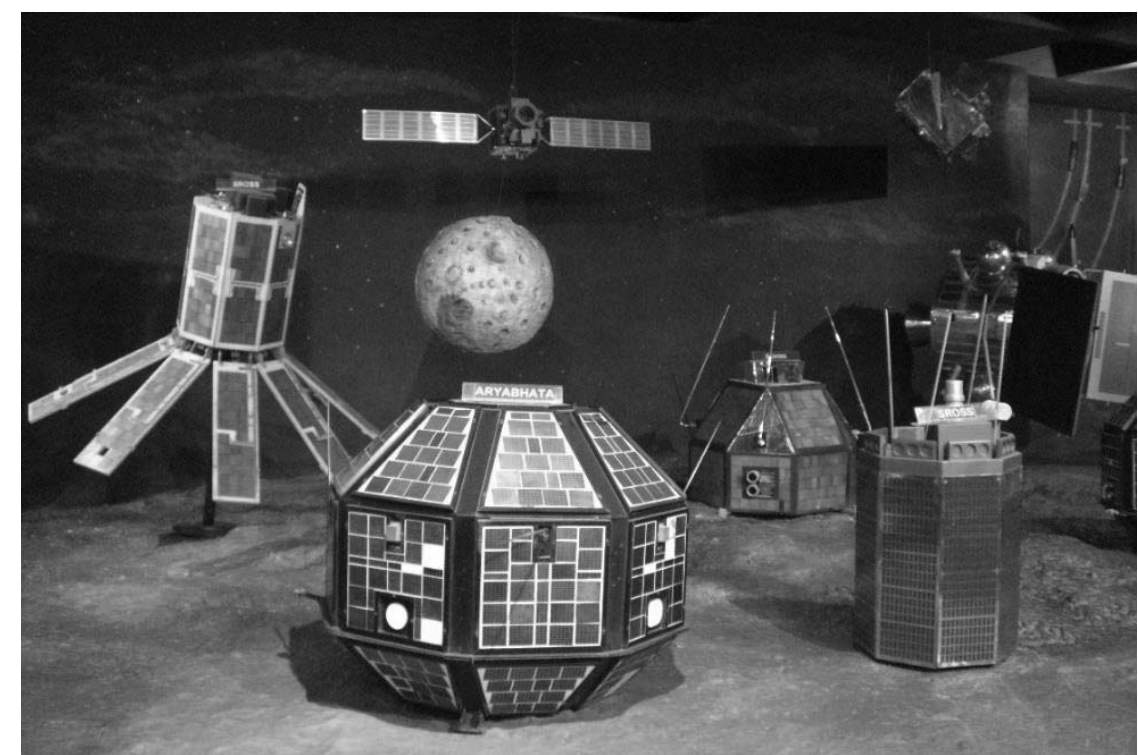

Експозиція, присвячена супутникам «Аріабата» і «Бхаскара». Промислово-технологічний музей ім. Вісвесварая, Бангалор.

Індійські фахівці отримали не тільки готові космічні апарати, як це пропонували західні країни, але завдяки радянським фахівцям навчилися самому процесу виробництва супутників, всім стадіям цього масштабного процесу. Надалі це сприяло стрімкому становленню та розвитку індійської космічної програми.

Проживання художника і мислителя С. М. Реріха в Індії поруч з Бангалором, містом науки і космосу, зумовило частий приїзд до нього не тільки відомих людей, але i вчених, інженерів i навіть космонавтів. Неодноразово приїжджали до Святослава Реріха і фахівці КБ «Південне», які згодом тепло згадували про ці зустрічі.

Індія показала нам дивовижний приклад того, як у досить короткі терміни можна досягти значних результатів. Так, у статті «Про проект Концепції Загальнодержавної космічної програми України на 2007-2011 роки» професор, директор Регіонального філіалу Національного інституту стратегічних досліджень у м. Дніпропетровську А. І. Шевцов зазначив: «...Показовим для наших умов $\epsilon$ приклад Індіі. Незважаючи на гострі соціально-економічні проблеми, країна взяла курс на прискорення розвитку вітчизняної космонавтики, обгрунтовано вбачаючи в ній рушійну силу розвитку вітчизняної науки і техніки» [7]. Вибравши ракетнокосмічну галузь основною і наукомісткою, Індія успішно розвиває і всі інші галузі знання, в тому числі і нанотехнологіi. І цієї мудрої позиції керівництва країни варто було б повчитися.

Співпраця ДП «КБ «Південне» 3 Індійською організацією космічних досліджень (ISRO), заснована на міцних наукових i культурних зв'язках, закладених в 70-ті роки XX століття, дасть можливість знайти нові шляхи розвитку наукового потенціалу i дозволить зміцнити космічну галузь України на міжнародному рівні. 


\section{References}

1. Roerich Svetoslav Nikolaevich: artist, enlightener, public figure. Website of the International Center of the Roerichs. URL: http:/www.icr.su/rus/family/snr/index.php.

2. Roerich N. K. (1999). Diary sheets. M.: International Center of the Roerichs, vol. I., 2nd ed. pp. 443-444 (in Russian).

3. Roerich S. N. (2004). Art and life. Translation from English by T. V. Kozhevnikova, I. I. Neitch. M.: International Center of the Roerichs; Master Bank, p. 114 (in Russian).

4. Popel A. M. Cooperation on the Ariabata-Bhaskara project in India. Interview taken by Olga Chaplits in 2007.

5. Summoned by time. From Confrontation to International Cooperation (2009). Under the General Ed. S. N. Konyukhov. 2nd ed., revised. and add. D.: «Art-Press», pp. 344369 (in Russian).

6. Svetoslav Roerich (2013). M.: International Center of the Roerichs, 32 p. (in Russian). 7. Chaplits O. A. (2009). Cooperation Yuzhnoye Design Office named after M. K. Yangel with the Indian Space Research Organization (ISRO). Space technology. Missile weapons. Comp. of scientific and technical articles. Dnepropetrovsk, Yuzhnoye Design Office (in Russian).

Received 28.01.2020

Received in revised form 11.02.2020

Accepted 20.02.2020 